\title{
Insights on Fructans and Resistance of Plants to Drought Stress
}

\section{Noureddine Benkeblia* \\ Department of Life Sciences - The Biotechnology Center, The University of the West Indies, Kingston, Jamaica}

Drought, one of the major abiotic stresses affecting plants, is characterized by a decrease of water availability, resulting in a decrease of the water potential $(\Psi)$ of the cells. One of the strategies of plants in resisting to this low $\Psi$ and related stresses is regulating their water-plant relation and the interplay between $\Psi$ solutes and the turgor pressure $(\Psi p)$. This regulation avoids the dehydration induced by low $\Psi$ and is resulting from the accumulation of specific molecules which induce higher tolerance to water deficit and also other mechanisms that prevent or repair cell damages. In plants, fructans, the nonstructural carbohydrates (NSC), have other physiological functions than carbon reserve. Among these roles, fructans have been implicated in protecting plants against water deficit caused by drought. As an efficient strategy to survive to this abiotic stress, plants synthesize fructans in response to osmotic pressure in order to osmoregulate the cellular flux, therefore, protecting the membrane damage and maintaining $\Psi \mathrm{p}$. Although different studies have been conducted to elucidate the mechanisms behind this strategy, still the concept itself is not well-understood and many points remain unclear and need to be elucidated in order to understand the causal relation between water deficit and fructans accumulation during water scarcity. This understanding will be a key tool in developing strategies to enhance crop tolerance to stressful dry conditions, particularly under the changing climate prediction. This review aims to give new insights on the roles of fructans in the response and resistance of plants to water deficit and their fate under this severe environmental condition.

\section{Keywords: fructans, abiotic stress, drought, resistance, plants}

\section{INTRODUCTION}

Fructans have a history of more than two centuries and some review articles have reported some historical aspects on fructans research (Meier and Reid, 1982; Pontis and Del Campillo, 1985; Pollock and Cairns, 1991). Prior to this exciting contemporary science, ancient peoples have been using fructans-containing plants as food, feed, and medicine. Indeed, the modern history of fructans began with their discovery by Rose (1804), and this history has known at the turn of the twentieth century considerable development when Edelman and Jefford proposed for the first time the mechanism of their metabolism in higher plants (Edelman and Jefford, 1964, 1968). More recently, fructans research has known a considerable progress particularly with the advancements of molecular biology moving fructans research from basic to applied science. Briefly and from the chemical and structural points of view, fructans are polyfructosylsucroses of varying molecular size build on a sucrose starter unit and are biochemically designated by $1 \mathrm{~F}$ (1- $\beta$-D-fructofuranosyl) $n$ sucrose oligomers where $n$ may vary depending on their types and degree of polymerization in different plant species (Figure 1). 


\section{Inulin type}

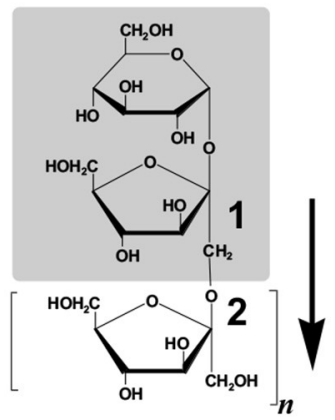

1-Kestose $(n=1)$

\section{Levan type}

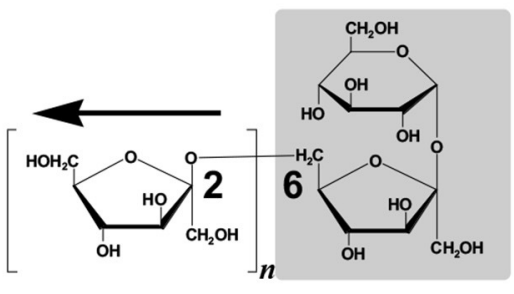

6-Kestose $(n=1)$

\section{Mixed type}

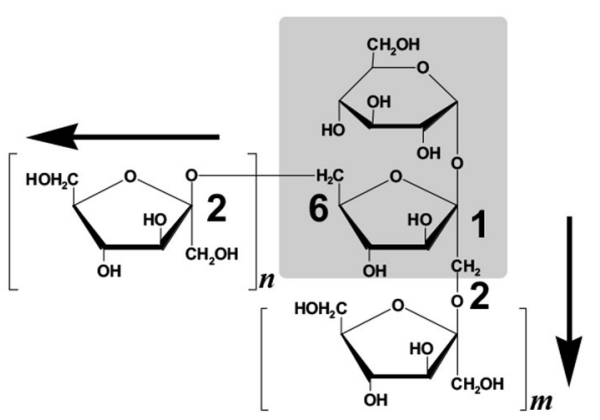

Bifurcose $(n=1, m=1)$

\section{Inulin neoseries}

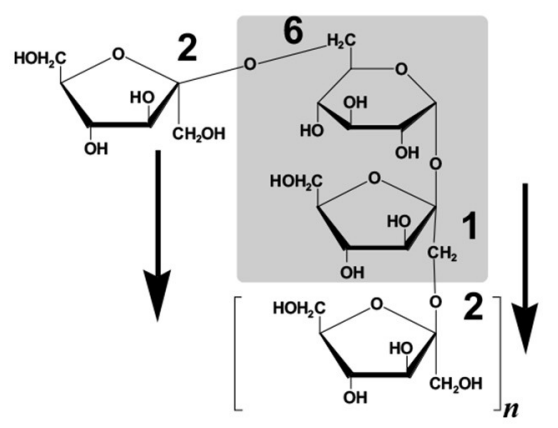

\section{Levan neoseries}

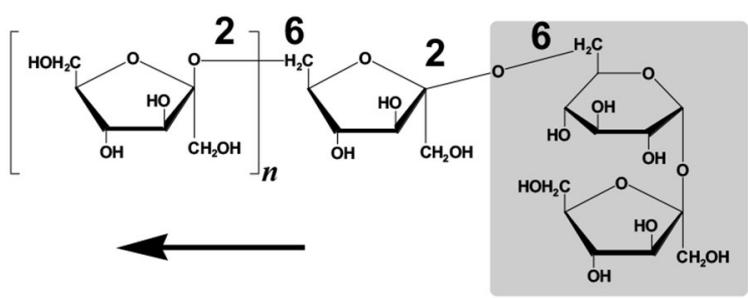

$6^{\mathrm{G}}(6-\beta-\mathrm{D}-\mathrm{fructofuranosyl})_{2}$ sucrose $(n=1)$

$1^{\mathrm{F}}, 6^{\mathrm{G}}$-Di- $\beta$-D-fructofuranosylsucrose $(n=1)$

FIGURE 1 | Molecular structures of the different types on fructan polymers found in higher plants.

Fructan polymers are found in c.a. 15\% of flowering plants, and the type and degree of polymerization vary with the species. In Asteraceae, inulin-type fructans of different degree of polymerization have been identified (Banguela and Hernández, 2006). For example, in chicory and Jerusalem artichoke low DP ranging from 10 to 30 units are found (Ernst et al., 1995; Vergauwen et al., 2003; Monti et al., 2005), while higher DP up to 200 units have been found in globe artichoke (Frehner et al., 1984). In contrary, in Monocot plants species such as Alliaceae, Asparagaceae, and Agavaceae more complex fructans are synthesized like inulin neo-series, and other branched types (see Figure 1). For example, in onion and garlic (Alliaceae) and asparagus (Asparagaceae) species, inulin and inulin neo-series are found ranging from 9 to 12 units in onion (Shiomi, 1989; Benkeblia and Shiomi, 2006), from 10 to 30 units in garlic (Das and Das, 1978; Baumgartner et al., 2000), and from 12 to 22 units in asparagus (Shiomi, 1993). In Agavaceae, another fructancontaining species, different types of fructan polymers were reported. Inulin type was found to be the principal fructan in Agave americana, however, inulin neo-series and other branched fructan types were identified in Agave vera cruz and Agave tequilana (Aspinall and Das Gupta, 1959; López et al., 2003).
As storage reserve, fructans are accumulated during the growth stage of the sink, then are catabolized during the regrowth and the development. However, fructans were found to have functions other than carbon storage: they have been implicated in protecting plants against water deficit or low temperature, inducing resistance to drought or cold stress/freezing (Hendry, 1993; Hendry and Wallace, 1993; Vijn and Smeekens, 1999) and as osmoregulators (Hendry, 1993; Livingston and Henson, 1998; Hincha et al., 2000). Although their metabolism and enzymes compartmentation have been elucidated (Frehner et al., 1984; Wagner and Wiemken, 1986), the molecular mechanisms behind their putative physiological roles still remain unclear.

Physiologically, fructans accumulate in plants as long-term or short-term carbohydrates reserve and are remobilized during the sprouting or regrowth. They are stored either in underground organs such as roots and tubers, or in stems, tiller bases and leaf sheaths (Incoll et al., 1989; Bancal et al., 1992; MorvanBertrand et al., 2001; Ranwala and Miller, 2008; Joaquim et al., 2014). Beside these roles, some studies have shown that fructan polymers might also be involved in the regulation of osmosis during flower opening (Le Roy et al., 2008), and the protection of plants against abiotic stresses (Hincha et al., 2003). In addition to 
these roles, some studies also investigated the possible alterations of the fructans pool and the photosynthetic responses of plants. For example, the depression of the photosynthesis did not affect the levels and fructans and the high DP pool was maintained even though mono- and disaccharide pools were affected (Marschall et al., 1998; Thomas and James, 1999; Marschall, 2010). In a similar study on different varieties of wheat and chicory, the depression of photosynthesis did not affect the accumulation of fructans, although hexoses pool was negatively correlated to the photosynthesis rate (Martínez-Carraseo et al., 1993; Monti et al., 2005).

As carbohydrate reserve, fructans are remobilized during regrowth of ryegrass (Chalmers et al., 2005; Trethewey and Rolston, 2009), cereals (Iannucci et al., 2016), or sprouting of onion (Pollock and Lloyd, 1994; Shiomi and Benkeblia, 2005; Yasin and Bufler, 2007), asparagus (Suzuki et al., 2013), and Jerusalem artichoke (Luo et al., 2018). Unlike in bacteria and fungi where two fructan hydrolases -one exo- and one endotypes- are found, different studies have demonstrated that in plants only the fructan exohydrolases (FEHs) releasing fructose units have been identified (Edelman and Jefford, 1968). These enzymes are supposed to not only breakdown fructans, but some evidences have shown they might play roles in plants signaling and defense (Van den Ende et al., 2004).

In general, plants are affected by biotic (e.g., resistance to diseases, parasites, insects, and weeds) or abiotic [e.g., better adaptation to heat, drought, salinity, acidity, heavy metals, waterlogging, and nutrient (especially nitrogen and phosphorus) availability)] stresses (Shao et al., 2008, 2009; Jahangir et al., 2009). Consequently, biotic and abiotic stresses cause significant losses in crops and productivity (Dita et al., 2006). Globally, the recent studies are predicting that water deficit or drought will increase in severity with the rising temperatures by 2100 (IPCC, 2019a). The effects of climate change will be reflected by either acute or chronic impacts associated with variable precipitation events and longer periods of drought. Africa will be among the most affected regions and yields of major crops will decrease significantly by more than $50 \%$ in 2050 and might reach $90 \%$ in 2100 for the major crops (Li et al., 2009; IPCC, 2019b). Therefore, improving water use efficiency (WUE) of crops is an imperative and needs to be addressed urgently, as this plant trait is seen as one of the most important solutions in addressing water scarcity and drought (Eslick and Hockett, 1974; Hamdy et al., 2003; Tuberosa and Salvi, 2006). On the other hand, there is a pressing need to improve WUE of either rain-fed or irrigated crops and breeding new varieties with optimal WUE by using either conventional breeding or molecular engineering seems to be the most environmentally friendly and sustainable solution to face water shortage and drought caused by climate in the future (Chaerle et al., 2005). However, prior to develop new crops or improve WUE of plants, we need to understand and decipher all the mechanisms developed by plants to face drought and their strategies to survive during short- and long-term dry periods. Indeed, plants encounter many unfavorable growth conditions including drought as one of the major abiotic environmental stress which limit their growth and development (Krasensky and Jonak, 2012). From the biological point of view, abiotic stresses include multiple ones, however, water deficit constitutes likely the major abiotic factor affecting plants (Sharma and Lavanya, 2002).

Under water scarcity, the biological roles of water as solvent, transporter, electron donor, and evaporative coolant were welldemonstrated to be impaired by environmental conditions (Hsiao, 1973; Bohnert et al., 1995). Nevertheless, sensitivity of plants to water deficit varies with the species and their responses to this abiotic stress, and therefore, they encoded different capabilities in their perception, signaling, and response to drought (Zhu, 2002; Shinozaki and Yamaguchi-Shinozaki, 2007; Shanker et al., 2014). Thus, plants respond to low water availability by modifying the concentration, composition, and distribution of the primary and secondary metabolites (Almeida et al., 2020). Within the context of climate change and the prediction of higher frequency of drought in many regions of the world, the challenge of metabolomics is to profile the widest range of primary and secondary metabolites that are present within plants during drought, and the comprehensive analysis shall reflect the exact biological fate of the plant system at both a defined developmental stage and under drought stress (Bowne et al., 2012). Experimental research and several biochemical studies reported that drought stress induce the accumulation of different metabolites in vascular and nonvascular plants (Bohnert and Jensen, 1996), and identifying the mechanisms underlying plant resilience to water deficits (Chaves and Oliveira, 2004), understanding carbon sequestration by plants per unit of transpired water (Condon et al., 2004) and the regulatory networks and specific metabolites involved in crop drought tolerance (Valliyodan and Nguyen, 2006) need to be further investigated.

This review aims to give recent and new insights on the roles of fructans in plants resistance to water deficit and their resilience to dry conditions. This review will also report recent evidences on the drought-protecting role of fructans and the mechanisms triggering these roles at organ and cellular levels.

\section{HOW DO PLANTS RESPOND TO DROUGHT STRESS?}

In response to water scarcity, plants have developed different but efficient mechanisms to adapt to this abiotic stress by activating resistance mechanisms at molecular and tissue levels. These mechanisms are multiple and metabolic adaptation, and regulation and molecular responses by triggering the biosynthesis of specific metabolites, are one of the most important of these multiple mechanisms (Seki et al., 2007; Nishizawa et al., 2008; Gargallo-Garriga et al., 2014; Fàbregas and Fernie, 2019).

Water deficit causes a reduction of the photosynthesis rate in the leaves and a decrease in the diffusion of atmospheric $\mathrm{CO}_{2}$ to the carboxylation site of RUBISCO (Flexas et al., 2004), and the decrease in the diffusion of $\mathrm{CO}_{2}$ is resulting from the stomatal closure (Chaves et al., 2003). The closure of stomata is likely the first response to water deficit and is mediated by $\mathrm{ABA}$ one the first phytohormones playing major roles in mediating plants response to stresses and synthesized in response to drought (Yoshida et al., 2014). ABA is known to trigger first the 
cascade of drought signaling (Urano et al., 2009; Lim et al., 2015; Shang et al., 2016; Li et al., 2017), and was shown to promote fructans accumulation by inducing further the expression of the 1-FFT (Fructan:fructan 1-fructosyltransferase) and 1-SST (Sucrose:sucrose 1-fructosyltransferase) genes in agave (SuárezGonzález et al., 2014). Indeed, drought stress is more complex that it seems, and plants' capacity to trigger physiology processes allowing tolerance to face drought stress are still not wellelucidated (El-Sayed et al., 2014). Although extensive literature is readily available on dehydration stress in a wide range of species, drought resistance still remains a complex mechanism and metabolomics techniques are one of the most used approaches to decipher this mechanism. On the other hand, the biosynthesis of protecting and stress-induced metabolites are induced by the expression of numerous stress-responsive genes in order to re-establish homeostasis and slowing down energy consuming processes which in turn induce tolerance to abiotic stress (Taylor et al., 2000; Hummel et al., 2010; Skirycz and Inzé, 2010; Seiler et al., 2011). By reducing energy consumption, carbon assimilation is redirected to activate protective mechanisms and stress-protecting metabolites among them fructans (Pilon-Smits et al., 1995; Van den Ende and Valluru, 2009; Keunen et al., 2013).

More generally, the induction of the production of stressprotecting metabolites or osmoprotectants is triggered by a cascade of signals starting by the induction of many genes expression involved in water scarcity response. Indeed, metabolites profiling and biology system studies have been good approaches for understanding the pathways of the molecular system mediating drought stress (Bowne et al., 2012). Different metabolomics studies showed that carbohydrates were among the most increased metabolites in response to drought stress (Rolland et al., 2006; Obata and Fernie, 2012; Ullah et al., 2017), and the levels of carbohydrates synthesis increases with the drought stress severity (Todaka et al., 2017).

\section{DROUGHT STRESS AND FRUCTANS ACCUMULATION}

One of the biochemical responses of plants to drought is the biosynthesis of non-structural carbohydrates (NSC) as osmoprotectants and adjusting the osmotic pressure by synthesizing osmo-protectants to avoid cell dehydration (Muller et al., 2011; Hou et al., 2018). Although not specific to fructans, the roles of the osmo-protecting molecules consist of stabilizing the cell membranes and cellular proteins from the denaturating effects of drought (Yancey, 1994). Additionally, osmo-protectors are thought to have many other roles like restoring the cellular redox by scavenging the reactive oxygen species (ROS), and balancing osmosis in order to preserve turgor, resulting in stabilization of protein and cellular structures (Pinhero et al., 1997; Zhu et al., 2003; Li et al., 2013). Among the accumulated metabolites as osmo-protectors, numerous carbohydrates, including fructose, sucrose, trehalose, raffinose, and fructans that are of high solubility, have been shown to accumulate in response to the increase in the osmotic pressure resulting from the dehydration (Rook et al., 1998; Nishizawa et al., 2008; Valluru and Van den Ende, 2008). The causation of fructans accumulation and drought stress was established by using plants transformed with bacterial fructosyltransferase genes (Cairns, 2003; Khan et al., 2015). In the 1990s, Pilon-Smits et al. (1999) used SacB gene from Bacillus subtilis to produce fructans in tobacco (Ebskamp et al., 1994; Pilon-Smits et al., 1995), potato (Van der Meer et al., 1994), and sugar beet (Pilon-Smits et al., 1999) which accumulated fructans under drought-induced condition and increased their resistance to water deficit. Studies carried out on the effects of drought on fructans biosynthesis in fructans nonaccumulating and transformed plants using genes of fructansaccumulating plant species have also showed similar results. Wheat-derived genes encoding fructans biosynthesis enzymes were transferred into tobacco plants which synthesized fructans under drought-induced stress (Bie et al., 2012). He et al. (2015) isolated a Psathyrostachys huashanica sucrose:fructan-6fructosyltransferase (Ph-6-SFT) and transferred it into tobacco (Nicotiana tabacum L.). By comparing the wild to the transgenic tobacco plants, they noted that the transformed plant exhibited a much higher tolerance of drought and this tolerance was associated with the accumulation of carbohydrate suggesting this approach might be applied as a genetic tool for improving stress tolerance in other crops. Similarly, the isolation of the fructan: fructan 1-fructosyl-transferase (1-FFT) gene from Jerusalem artichoke and its overexpression in the leaves of transgenic tobacco increased their fructans biosynthesis under simulated drought (Sun et al., 2020). In non-transformed plants, the response and accumulation of fructans in response to drought stress was first reported by Virgona and Barlow (1991) who observed that turgor of wheat stem was maintained with an increase in NSC. Later, other research reported similar results on drought-induced fructans biosynthesis in chicory (De Roover et al., 2000), wheat (Zhang et al., 2015; Hou et al., 2018), Vernonia herbacea (Garcia et al., 2011), and lettuce (Blanch et al., 2017).

However, these numerous studies did not elucidate the mechanisms of how fructans contribute to enhancing drought stress tolerance either in the transformed plants which accumulate low level of fructans or non-transformed plants which accumulate significant levels of these osmoregulators. On the hand, the mechanism by which these osmolytes provide protection is still unclear and not completely understood (Ramanjulu and Bartels, 2002; Du et al., 2004; Reddy et al., 2004; Arbona et al., 2013; Fedotova, 2019), although it is hypothesized that fructan polymers might act by regulating water potential, signaling molecules and/or ROS scavengers, therefore, affecting the metabolism of plants under drought conditions (BolouriMoghaddam et al., 2010; Van den Ende, 2013; Ahmad et al., 2020).

\section{FRUCTANS METABOLISM AS DROUGHT PROTECTIVE MECHANISMS}

Demel et al. (1998) first suggested an interesting in-vitro model on the protective role of fructans during drought. From the results of their experiment, the authors suggested that fructans cause a very large increase in surface pressure of lipid 
monolayers, hence hypothesizing that lipid condensation and phase transitions might be prevented by membrane-fructan interaction, thus inducing the drought protective effect. Later, a similar model of the protective effect of fructans on liposomes by assessing their stability during either air draying or drying and rehydration was suggested (Hincha et al., 2002, 2007). Results showed that low DP 3, DP 4, and DP 5 fructans exhibited higher protective action by preventing leakage of a soluble marker from liposomes and liposome fusion. The same study is however suggesting that this protective action of fructans depends on their size and origin, and their compartmented protective properties might differ significantly compared to the purified fractions (Hincha et al., 2007). Getting a deeper insight into the mechanism of this protective effect on the cellular membrane during dehydration, different fructans have been tested on phosphatidylcholine-based model systems. Results clearly showed that inulin-type fructans protected the membrane barrier and inhibited vesicle fusion by their presence between the lipid bilayers during drying, thus, confirming their membraneprotecting role during dehydration (Vereyken et al., 2003). Indeed, the protective action of fructans was attributed to their capacity to insert between the lipids of the membrane. The hypothesis of the membrane stabilization by fructans during drought is based on their capacity of binding lipid molecules forming a glass, therefore, reducing the movement of the membrane molecules and this pseudo-rigidity is behind their protective effects (Hinrichs et al., 2001; Vereyken et al., 2003).

Another inevitable consequence of drought response in plants is the production of reactive oxygen species (ROS) and this production is linked to ABA signaling (Cruz de Carvalho, 2008; Hasanuzzaman et al., 2014; Kaur and Asthir, 2015; Hussain et al., 2019). This excess production of ROS known as oxidative burst, is one of the responses of plants to drought triggering defense reaction in plants. Under drought stress, the induction of ROS-generating systems or attenuated ROS scavenging is associated with the damaging oxidative effect and the modifications of cell biomolecules leading the disruption of cellular homeostasis, causing damages to cell and even its death (Mittler, 2017; Janku et al., 2019). Consequently, plants developed two main strategies to control excessive ROS production and reducing cell damages. The first detoxification strategy is achieved by a complex enzymatic system including numerous enzymes such as superoxide dismutase (SOD), catalase (CAT), ascorbate peroxidase (APX), and glutathione reductase (GR; Noctor and Foyer, 1998). The second detoxification strategy is achieved by some primary and secondary metabolites possessing antioxidant and scavenging properties such as ascorbic acid, glutathione, carotenoids, tocopherols, and phenolic compounds (Noctor and Foyer, 1998; Isah, 2019). Therefore, this capacity to maintain an antioxidant activity by scavenging ROS has been associated to tolerance of plants to drought and other abiotic stresses as well (Sharma et al., 2012; Noctor et al., 2014). From the biochemical point of view, the metabolic compartmentation of ROS are the chloroplasts, mitochondria, and peroxisomes under light condition, while under darkness, the mitochondria are the main compartment of ROS production (Choudhury et al., 2014). Consequently, during environmental stresses an overproduction of ROS in plants due to disruption of cellular homeostasis, triggers undesirable processes such as lipids peroxidation, proteins oxidation, damage to nucleic acids, enzymes inhibition, and even programmed cell death (PCD) activation ultimately leading to death of the cells [Sharma et al., 2012; see Hasanuzzaman et al. (2020)]. Enhanced production of ROS has also been shown to increase the production of malondialdehyde (MDA) considered as an indicator of oxidative damage and a marker-metabolite of membrane lipid peroxidation (Moller et al., 2007; Ayala et al., 2014; Morales and Munné-Bosch, 2019).

Interestingly, numerous studies have reported the antioxidant (AOA) power of sugars (Faraji and Lindsay, 2004; Couée et al., 2006; Cherkas et al., 2020) by quenching ROS and contributing to stress tolerance (Bolouri-Moghaddam et al., 2010), and this AOA activity seems to be enhanced when sugars interact with phenolic compounds (Faraji and Lindsay, 2004; Lončarić et al., 2018). More interestingly, fructans were also reported to possess antioxidant properties in vitro (Stoyanova et al., 2011; Peshev et al., 2013; Pasqualetti et al., 2014).

Fructans, and other sugars as well, have been shown to be better ${ }^{\circ} \mathrm{OH}$ radical scavengers in comparison with $\mathrm{O}_{2}^{\circ}-$ (Stoyanova et al., 2011). Since plants do not possess an enzymatic ${ }^{\circ} \mathrm{OH}$ scavenging mechanisms, high concentrations of nonenzymatic antioxidants mechanism are used to neutralize ROS (Gechev et al., 2006). Furthermore, in-vitro studies demonstrated good ROS scavenging properties of fructans (Peshev et al., 2013), and similar reactions are thought to occur in planta, especially at higher concentrations (Uemura and Steponkus, 2003). This capacity of fructans for capturing ROS in a wide range of stresses was also highlighted by the study of Nemati et al. (2018) who noted an increase of fructans accumulation accompanied by increased $\mathrm{OH}$ radical scavenging activity in 4-day-old seedlings of wheat during drought stress.

Although numerus studies have demonstrated the membraneprotecting roles of the antioxidant activities of fructans, two questions remain yet to be fully answered. Since fructans are synthesized and stored in the vacuolar compartment (Darwen and John, 1989), the first question is how fructans polymers are transported from the vacuole to reach the plasma membrane?

The first clue to explain the solutes flux out of the vacuole is the primary functions of many cells of roots, tubers, and rhizomes to mobilize vacuolar components during the regrowth because as a storage compartment, vacuole is intimately involved in the export of the stored metabolites to their final destination either cytosol or apoplast (Etxeberria et al., 2012). Indeed, fructans are supposed to be transported out of the vacuole similarly to sugars. Because of their high concentration in the vacuole, solutes do not require active transporters. Functional analyses of monosaccharide transporters (Schulz et al., 2011) and sucrose-symporters (Schneider et al., 2011; Schulz et al., 2011) showed the ability of these transporters to efflux from the vacuolar compartment under appropriate conditions and this efflux is controlled by their concentration gradients. Therefore, it could be hypothesized that fructans might be transported and channeled by their specific transporter or passively through anion channels like other solutes 
(Blumwald and Poole, 1985; van der Leij et al., 1998; Kataoka et al., 2004; Poschet et al., 2011). However, this hypothesis raises another question on the mode of action of these specific transporters, although the evidence of glucose transporter was reported in Arabidopsis (Poschet et al., 2011), further investigation is needed to elucidate the mode of actions of the potential transporters of fructans and this hypothetical transport pathway.

The second question is related to the ability of fructans to scavenge ROS. Although the question remains yet unclear and the scavenging mechanisms of ROS by sugars not clearly established. Nevertheless, from the chemical and biochemical points of view different studies established the association between soluble sugars accumulation and ROS induced by the high photosynthetic rate in the source leaves (Scarpeci and Valle, 2008; Van den Ende and Valluru, 2009), and similarly sugars starvation also induced ROS accumulation (Couée et al., 2006). On the other hand, sugars have also been found to interact with secondary metabolites known for their strong scavenging power and antioxidants capacities (Bolouri-Moghaddam et al., 2010; Peshev et al., 2013). A study conducted in vitro showed that sugars might act jointly with the phenolic compounds in ROS detoxification and the cytosolic antioxidant mechanisms (Van den Ende and El-Esawe, 2013). However, many studies suggest that sugars have direct role in ROS scavenging, but they also act indirectly by triggering other pathways such as the oxidative-pentose phosphate pathway (OPP) which in turn might trigger ROS scavenging (Debnam et al., 2004). Nevertheless, direct or indirect ROS-detoxification roles of sugars including fructans make a strong consensus, and a synergetic interaction between sugars and phenolics form a valuable part of the redox system contributing significantly to abiotic stress tolerance. Nevertheless, the chemical and biochemical mechanisms behind these actions remain still unclear and not clearly elucidated, therefore, requiring further investigation.

\section{FRUCTANS METABOLISM AS CELLULAR MECHANISM OF DROUGHT ADJUSTMENT}

Under drought conditions, higher plants were reported to decrease their photosynthetic rate consequently to the decrease of leaf water potential and relative water content (Lawlor and Cornic, 2002), however, there is still a controversy on whether drought limits photosynthetic $\mathrm{CO}_{2}$ assimilation through stomatal closure or by metabolic impairment in C3 plants (Bunce, 1988; Flexas and Medrano, 2002; Lawson et al., 2003). The different studies are suggesting that the decrease in the photosynthesis rate is caused by stomatal closure in the earliest response of plants at mild to moderate drought, while the downregulation or inhibition of metabolic processes leading to a drastic decrease of RUBISCO is the response of plants to sever drought (Flexas and Medrano, 2002).

On the other hand, it is well-established that sugar metabolism is controlled by phytohormones, specifically abscisic acid (ABA) which is the principal regulator of enzymes and transcript involved in the synthesis pathways and accumulation of carbohydrates including fructans (Van Den Ende et al., 2002; Trouverie et al., 2003; Yang et al., 2004). Indeed, the hormonal regulation of fructans-metabolizing enzymes was first suggested by Bausewein et al. (2012), ABA appears to positively affect reserve of carbon storage in plants and promoting the accumulation of fructans by increasing gene expressions of 1FFT and 1-SST (Suárez-González et al., 2014; Gasperl et al., 2016). For example, application of exogenous ABA induced an increase of fructans in chicory (Wei et al., 2016), however, in a recent study Mohammadi et al. (2021) reported on the hormonal interaction mechanisms for fructan content and their degree of polymerization (DP). Interestingly, the authors noted that inulin DP increased by an application of exogenous ABA which also interacted by changing and adjusting the effect of auxin (AUX) and ethylene (ETH) hormones. Using chicory as plant model, Michiels et al. (2004) have also demonstrated the response of 1$\mathrm{FEH}$ to ABA and other plant growth regulators, highlighting the complexity of fructans metabolism and it's the regulation.

For the stomatal point of view, the regulation of stomata is complex, and its regulation varies with species and their response to water potential and ABA signal, thus, the mechanisms of the photosynthetic responses to drought is blurry (Liang et al., 1997; Reddy et al., 2004). It was admitted that low water potential in the soil triggers a root-to-leaf chemical (ABA) signal inducing a decrease of water potential and relative water content (RWC) in leaves (Epstein and Grant, 1973; Jones and Turner, 1978; Siddique et al., 2000), triggering therefore stomatal closure, and decrease in the photosynthesis rate (Downton et al., 1988; Cornic, 2000; Escalona et al., 2000).

Morphologically, drought was reported to decrease the rate of leaf expansion by reducing the expansion of the existing cells when root water potential decreases sharply (Munns and Sharp, 1993; Nelissen et al., 2018; Koch et al., 2019), while cell division rate is slowed down under mild drought (Schuppler et al., 1998; Tardieu et al., 2000).

From the metabolic point of view, the biosynthesis of solutes, namely osmoprotectors, is one of the strategies of plants to response and cope with osmotic stress resulting from drought. In order to prevent water loss and maintain cell turgor, plants accumulate numerous solutes, and fructans are one of these major compounds which play a role in osmotic adjustment, membrane protection and ROS scavenging (Pinhero et al., 1997; Hare et al., 1998). Different studies reported the high demand of osmolytes biosynthesis during drought with changes in carbohydrate metabolism and fructans accumulation (Hare et al., 1998; Xue et al., 2008; Ozturk et al., 2021), and interestingly this accumulation even though accompanied by a decrease in the photosynthesis rate, might increase yields of crops (Serraj and Sinclair, 2002). However, the mechanisms of solutes accumulation and osmotic adjustment are not fully understood, one of the hypotheses is that since drought reduces cell division and expansion, fructans accumulate because there are not consumed in growth although no evidence of 'competition' between growth and osmotic adjustment for metabolites was noted (Thomas, 1990). This observation agrees with the findings of Garcia et al. (2011) who reported an increase of fructans synthesizing enzymes (1-SST and 1-FFT) and a decrease in the fructans hydrolyzing enzymes (1-FEH) at the onset of the reduction in soil water and leaf water potential. These findings show well that fructan metabolism is undoubtedly 
thought to be involved in osmotic adjustment, and fructans are indirectly contributing to this adjustment (Spollen and Nelson, 1994).

\section{CONCLUSION AND FUTURE PROSPECTS}

Water scarcity is one of the most important abiotic stresses and might be a consequence of many events such as rainfall deficit or high temperatures. This multidimensional stress is associated to many physiological, biochemical, and molecular changes and responses to drought stress. Indeed, plants depict a wide range of responses drought stress and ability to withstand water scarcity which differs from species to species. Thus, many plants developed different mechanisms to better resist, cope and even resile to or from drought, and fructans biosynthesis is one of these developed biochemical mechanisms in order to maintain cell homeostasis under water-scarcity conditions. It is also well-established that occurrence of drought causes the osmotic disturbance and oxidative stress, and fructans have been demonstrated to play a role in counter-balancing these adversities.

Beside the significant advances made on fructans and their osmoprotective roles, and the various experimental approaches tested to understand the biochemical and molecular mechanisms behind these roles, yet numerous questions remain not answered.

\section{REFERENCES}

Ahmad, A., Singh, A., and Kamal, A. (2020). "Osmoprotective role of sugar in mitigating abiotic stress in plants," in Protective Chemical Agents in the Amelioration of Plant Abiotic Stress: Biochemical and Molecular Perspectives, eds A. Roychoudhury and D. K. Tripat (Hoboken, NJ: John Wiley \& Sons Ltd), 53-70. doi: 10.1002/9781119552154.ch3

Almeida, T., Pinto, G., Correia, B., Gonçalves, S., Meijón, M., and Escandón, M. (2020). In-depth analysis of the Quercus suber metabolome under drought stress and recovery reveals potential key metabolic players. Plant Sci. 299:110606. doi: 10.1016/j.plantsci.2020.110606

Arbona, V., Manzi, M., de Ollas, C., and Gómez-Cadena, A. (2013). Metabolomics as a tool to investigate abiotic stress tolerance in plants. Int. J. Mol. Sci. 14, 4885-4911. doi: 10.3390/ijms14034885

Aspinall, G. O., and Das Gupta, P. C. (1959). The structure of the fructosan from Agave vera cruz Mill. J. Am. Chem. Soc. 81, 718-722. doi: 10.1039/jr9590000718

Ayala, A., Muñoz, M. F., and Argüelles, S. (2014). Lipid peroxidation: production, metabolism, and signaling mechanisms of malondialdehyde and 4-hydroxy-2nonenal. Oxid. Med. Cell. Longev. 2014:360438. doi: 10.1155/2014/360438

Bancal, P., Carpita, N. C., and Gaudillère, J. P. (1992). Differences in fructan accumulation in induced and field-grown wheat plants: an elongationtrimming pathway for their synthesis. New Phytol. 120, 313-321. doi: 10.1111/j.1469-8137.1992.tb01071.x

Banguela, A., and Hernández, L. (2006). Fructans: from natural sources to transgenic plants. Biotecnol. Aplic. 23, 202-210.

Baumgartner, S., Dax, T. G., Praznik, W., and Falk, H. (2000). Characterisation of the high- molecular weigh fructan isolated from garlic (Allium sativum L.). Carbohydr. Res. 328, 177-183. doi: 10.1016/S0008-6215(00)00097-5

Bausewein, A., Greiner, S., Harms, K., and Rausch, T. (2012). "Hormonal regulation of fructan active enzymes in chicory (Cichorium intybus)," in Abstracted Presented at the 7th International Fructan Symposium (IFS), July 2-6 2012, Saint-Jean-le-Thomas.

Benkeblia, N., and Shiomi, N. (2006). Fructooligosaccharides of edible Alliums: occurrence, chemistry and health benefits. Curr. Nutr. Food Sci. 2, 181-191. doi: $10.2174 / 157340106776818808$
For proper understanding of the physiological, biochemical and molecular mechanisms of plants responses to drought and the roles and fate of fructans during and after drought, further investigations are needed. Among the major questions we need to elucidate (i) why fructans content increase during drought while photosynthesis decreases, (ii) how fructans are decompartmentalized from the vacuoles to protect the membrane, (iii) what the mechanism of ROS scavenging by fructans is, and (iv) last but not least how fructans interact with phenolics to scavenge ROS. Indeed, different hypotheses have been suggested to clearly answer these questions, but more scientific evidences are need in order to clarify the blurry picture we have. Obviously, modern technologies including genomics, transcriptomics, proteomics and metabolomics might be very useful in elucidating these mechanisms and pathways. Consequently, with these techniques, it is likely possible to develop a sophisticated and efficient network in crops response to drought stresses and subsequently help significantly in the improvement of drought-tolerance and productivity of crops.

\section{AUTHOR CONTRIBUTIONS}

The author confirms being the sole contributor of this work and has approved it for publication.

Bie, X., Wang, K., She, M., Du, L., Zhang, S., Li, J., et al. (2012). Combinational transformation of three wheat genes encoding fructan biosynthesis enzymes confers increased fructan content and tolerance to abiotic stresses in tobacco. Plant Cell Rep. 31, 2229-2238. doi: 10.1007/s00299-012-1332-y

Blanch, M., Alvarez, M. D., Sanchez-Ballesta, M. T., Escribano, M. I., and Merodio, C. (2017). Water relations, short-chain oligosaccharides and rheological properties in lettuces subjected to limited water supply and low temperature stress. Sci. Hortic. 225, 726-735. doi: 10.1016/j.scienta.2017. 08.002

Blumwald, E., and Poole, R. J. (1985). Nitrate storage and retrieval in Beta vulgaris: effects of nitrate and chloride on proton gradients in tonoplast vesicles. Proc. Natl Acad. Sci. USA. 82, 3683-3687. doi: 10.1073/pnas.82.11.3683

Bohnert, H. J., and Jensen, R. G. (1996). Strategies for engineering water-stress tolerance in plants. Trends Biotechnol. 14, 89-97. doi: 10.1016/0167-7799(96)80929-2

Bohnert, H. J., Nelson, D. E., and Jensen, R. G. (1995). Adaptations to environmental stresses. Plant Cell. 7, 1099-1111. doi: 10.2307/3870060

Bolouri-Moghaddam, M. R., Le Roy, K., Xiang, L., Rolland, F., and Van den Ende, W. (2010). Sugar signalling and antioxidant network connections in plant cells. FEBS J. 277, 2022-2037. doi: 10.1111/j.1742-4658.2010.07633.x

Bowne, J. B., Erwin, T. A., Juttner, J., Schnurbusch, T., Langridge, P., Bacic, A., et al. (2012). Drought responses of leaf tissues from wheat cultivars of differing drought tolerance at the metabolite level. Mol. Plant 5, 418-429. doi: $10.1093 / \mathrm{mp} / \mathrm{ssr} 114$

Bunce, J. A. (1988). Nonstomatal inhibition of photosynthesis by water stress. Reduction in photosynthesis at high transpiration rate without stomatal closure in field-grown tomato. Photosynth. Res. 18, 357-362. doi: 10.1007/BF00034840

Cairns, A. J. (2003). Fructan biosynthesis in transgenic plants. J. Exp. Bot. 54, 549-567. doi: 10.1093/jxb/erg056

Chaerle, L., Saibo, N., and Van Der Straeten, D. (2005). Tuning the pores: towards engineering plants for improved water use efficiency. Trends Biotechnol. 23, 308-315. doi: 10.1016/j.tibtech.2005.04.005

Chalmers,. J., Lidgett, A., Cummings, N., Cao, Y., Forster, J., and Spangenberg, G. (2005). Molecular genetics of fructan metabolism in perennial ryegrass. Plant Biotechnol. J. 3, 459-474. doi: 10.1111/j.1467-7652.2005.00148.x 
Chaves, M. M., Maroco, J. P., and Pereira, J. S. (2003). Understanding plant responses to drought-from genes to the whole plant. Funct. Plant Biol. 30, 239-264. doi: 10.1071/FP02076

Chaves, M. M., and Oliveira, M. M. (2004). Mechanisms underlying plant resilience to water deficits: prospects for water-saving agriculture. J. Exp. Bot. 55, 2365-2384. doi: 10.1093/jxb/erh269

Cherkas, A., Holota, S., Mdzinarashvili, T., Gabbianelli, R., and Zarkovic, N. (2020). Glucose as a major antioxidant: when, what for and why it fails? Antioxidants 9:140. doi: 10.3390/antiox9020140

Choudhury, S., Panda, P., Sahoo, L., and Panda, S. K. (2014). Reactive oxygen species signaling in plants under abiotic stress. Plant Signal. Behav. 8:e236811. doi: $10.4161 /$ psb.23681

Condon, A. G., Richards, R. A., Rebetzke, G. J., and Farquhar, G. D. (2004). Breeding for high water-use efficiency. J. Exp. Bot. 55, 2447-2460. doi: $10.1093 /$ jxb/erh277

Cornic, G. (2000). Drought stress inhibits photosynthesis by decreasing stomatal aperture - not by affecting ATP synthesis. Trends Plant Sci. 5, 187-188. doi: 10.1016/S1360-1385(00)01625-3

Couée, I., Sulmon, C., Gouesbet, G., and Amrani, A. E. (2006). Involvement of soluble sugars in reactive oxygen species balance and responses to oxidative stress in plants. J. Exp. Bot. 57, 449-459. doi: 10.1093/jxb/erj027

Cruz de Carvalho, M. H. (2008). Drought stress and reactive oxygen species. Production, scavenging and signaling. Plant Signal. Behav. 3, 156-165. doi: $10.4161 / \mathrm{psb} .3 .3 .5536$

Darwen, C. W. E., and John, P. (1989). Localization of the enzymes of fructan metabolism in vacuoles isolated by a mechanical method from tubers of Jerusalem artichoke (Helianthus tuberosus L.). Plant Physiol. 89, 658-663. doi: $10.1104 /$ pp.89.2.658

Das, N. N., and Das, A. (1978). Structure of the D-fructan isolated from garlic (Allium sativum) bulbs. Carbohydr. Res. 64, 155-167. doi: 10.1016/S0008-6215(00)83697-6

De Roover, J., Vandenbranden, K., Van Laere, A., and Van den Ende, W. (2000). Drought induces fructan synthesis and 1-SST (sucrose: sucrose fructosyltransferase) in roots and leaves of chicory seedlings (Cichorium intybus L.). Planta 210, 808-814. doi: 10.1007/s004250050683

Debnam, P. M., Fernie, A. R., Leisse, A., Golding, A., Bowsher, C. G., Grimshaw, C., et al. (2004). Altered activity of the P2 isoform of plastidic glucose-6-phosphate dehydrogenase in tobacco (Nicotiana tabacum cv. Samsun) causes changes in carbohydrate metabolism and response to oxidative stress in leaves. Plant J. 38, 49-59. doi: 10.1111/j.1365-313X.2004.02017.x

Demel, R. A., Dorrepaal, E., Ebskamp, M. J. M., Smeekens, J. C. M., and de Kruij, B. (1998). Fructans interact strongly with model membranes. Biochim. Biophys. Acta 1375, 36-42. doi: 10.1016/S0005-2736(98)00138-2

Dita, M. A., Rispail, N., Prats, E., Prats, E., Rubiales, D., and Singh, K. B. (2006). Biotechnology approaches to overcome biotic and abiotic stress constraints in legumes. Euphytica 147, 1-24. doi: 10.1007/s10681-006-6156-9

Downton, W. J. S., Loveys, B. R., and Grant, W. J. R. (1988). Stomatal closure fully accounts for the inhibition of photosynthesis by abscisic acid. New Phytol. 108, 263-266. doi: 10.1111/j.1469-8137.1988.tb04161.x

Du, J., Chen, X., Li, W., and Gao, Q. (2004). Osmoregulation mechanism of drought stress and genetic engineering strategies for improving drought resistance in plants. For. Stud. China 6, 56-62. doi: 10.1007/s11632-0040021-5

Ebskamp, M. J. M., van der Meer, I. M., Spronk, B. A., Weisbeek, P. J., and Smeekens, S. C. M. (1994). Accumulation of fructose polymers in transgenic tobacco. Biotechnology 12, 272-275. doi: 10.1038/nbt0394-272

Edelman, J., and Jefford, T. G. (1964). The metabolism of fructose polymers in plants. Fi-Fructofuranosidases of tubers of Helianthus tuberosus L. Biochem. J. 93, 148-161. doi: 10.1042/bj0930148

Edelman, J., and Jefford, T. G. (1968). The mechanism of fructosan metabolism in higher plants as exemplified in Helianthus tuberosus. New Phytol. 67, 517-531. doi: 10.1111/j.1469-8137.1968.tb05480.x

El-Sayed, A. I., Rafudeen, M. S., and Golldack, D. (2014). Physiological aspects of raffinose family oligosaccharides in plants: protection against abiotic stress. Plant Biol. 16, 1-8. doi: 10.1111/plb.12053

Epstein, E., and Grant, W. J. (1973). Water stress relations of the potato plant under field conditions. Agronomy J. 65, 400-404. doi: 10.2134/agronj1973.00021962006500030015x
Ernst, M., Chatterton, N. J., and Harrison, P. A. (1995). Carbohydrate changes in chicory (Cichorium intybus L. var. foliosum) during growth and storage. Sci. Hortic. 63, 251-261. doi: 10.1016/0304-4238(95)00815-B

Escalona, J. M., Flexas, J., and Medrano, H. (2000). Stomatal and non-stomatal limitations of photosynthesis under water stress in field-grown grapevines. Aust. J. Plant Physiol. 27, 87-87. doi: 10.1071/PP99019_CO

Eslick, R. F., and Hockett, E. A. (1974). Genetic engineering as a key to water-use efficiency. Agric. Meteorol. 14, 13-23. doi: 10.1016/0002-1571(74)90006-5

Etxeberria, E., Pozueta-Romero, J., and Gonzalez, P. (2012). In and out of the plant storage vacuole. Plant Sci. 190, 52-61. doi: 10.1016/j.plantsci.2012.03.010

Fàbregas, N., and Fernie, A. R. (2019). The metabolic response to drought. J. Exp. Bot. 70, 1077-1085. doi: 10.1093/jxb/ery437

Faraji, H., and Lindsay, R. C. (2004). Characterization of the antioxidant activity of sugars and polyhydric alcohols in fish oil emulsions. J. Agric. Food Chem. 52, 7164-7711. doi: 10.1021/jf035291k

Fedotova, M. V. (2019). Compatible osmolytes - bioprotectants: is there a common link between their hydration and their protective action under abiotic stresses? J. Mol. Liq. 292:11133. doi: 10.1016/j.molliq.2019.111339

Flexas, J., Bota, J., Loreto, F., Cornic, G., and Sharkey, T. D. (2004). Diffusive and metabolic limitations to photosynthesis under drought and salinity in C3 plants. Plant Biol. 6, 269-279. doi: 10.1055/s-2004-820867

Flexas, J., and Medrano, H. (2002). Drought-inhibition of photosynthesis in C3 plants: stomatal and non-stomatal limitation revisited. Ann. Bot. 89, 183-189. doi: $10.1093 / \mathrm{aob} / \mathrm{mcf027}$

Frehner, M., Keller, F., and Wiemken, A. (1984). Localization of fructan metabolism in the vacuoles isolated from protoplasts of Jerusalem artichoke tubers (Helianthus tuberosus L). J. Plant Physiol. 116, 197-208. doi: 10.1016/S0176-1617(84)80089-9

Garcia, P. M. A., Asega, A. F., Silva, E. A., and Carvalho, M. A. M. (2011). Effect of drought and re-watering on fructan metabolism in Vernonia herbacea (Vell.) Rusby. Plant Physiol. Biochem. 49, 664-670. doi: 10.1016/j.plaphy.2011.03.014

Gargallo-Garriga, A., Sardans, J., Pérez-Trujillo, M., Rivas-Ubach, A., Oravec, M., Vecerova, K., et al. (2014). Opposite metabolic responses of shoots and roots to drought. Sci. Rep. 4:6829. doi: 10.1038/srep06829

Gasperl, A., Morvan-Bertrand, A., Prud'homme, M. P., van der Graaff, E., and Roitsch, T. (2016). Exogenous classic phytohormones have limited regulatory effects on fructan and primary carbohydrate metabolism in perennial ryegrass (Lolium perenne L.). Front. Plant Sci. 6:1251. doi: 10.3389/fpls.2015.01251

Gechev, T. S., Van Breusegem, F., Stone, J. M., Denev, I., and Laloi, C. (2006). Reactive oxygen species as signals that modulate plant stress responses and programmed cell death. BioEssays 28, 1091-1101. doi: 10.1002/bies.20493

Hamdy, A., Ragab, R., and Scarascia-Mugnozza, E. (2003). Coping with water scarcity: water saving and increasing water productivity. Irrig Drain 52, 3-20. doi: 10.1002/ird.73

Hare, P. D., Cress, W. A., and Van Staden, J. (1998). Dissecting the roles of osmolyte accumulation during stress. Plant Cell Environ. 21, 535-553. doi: 10.1046/j.1365-3040.1998.00309.x

Hasanuzzaman, M., Borhannuddin Bhuyan, M. H. M., Zulfiqar, F., Raza, A., Mohsin, S. M., Al Mahmud, J., et al. (2020). Reactive oxygen species and antioxidant defense in plants under abiotic stress: revisiting the crucial role of a universal defense regulator. Antioxidants 9:681. doi: 10.3390/antiox9080681

Hasanuzzaman, M., Nahar, K., Gill, S. S., and Fujita, M. (2014). "Drought stress responses in plants, oxidative stress, and antioxidant defense," in Climate Change and Plant Abiotic Stress Tolerance, eds N. Tuteja and S. S. Gill (Berlin: Wiley-VCH Verlag GmbH), 209-249. doi: 10.1002/9783527675265.ch09

He, X., Chen, Z., Wang, J., Li, W., Zhao, J., Wu, J., et al. (2015). A sucrose:fructan-6-fructosyltransferase (6-SFT) gene from Psathyrostachys huashanica confers abiotic stress tolerance in tobacco. Gene 570, 239-247. doi: 10.1016/j.gene.2015.06.023

Hendry, G. A. F. (1993). Evolutionary origins and natural functions of fructansa climatological, biogeographical and mechanistic appraisal. New Phytol. 123, 3-14. doi: 10.1111/j.1469-8137.1993.tb04525.x

Hendry, G. A. F., and Wallace, R. K. (1993). "The origin, distribution, and evolutionary significance of fructans," in Science and Technology of Fructans, eds M. Suzuki and N. J. Chatterton (Boca Raton, FL: CRC Press), 119-139.

Hincha, D. K., Hellwege, E. M., Heyer, A. G., and Crowe, J. H. (2000). Plant fructans stabilize phosphatidylcholine liposomes during freeze-drying. Eur. J. Biochem. 267, 535-540. doi: 10.1046/j.1432-1327.2000.01028.x 
Hincha, D. K., Livingston, D. P. I. I. I., Premakumar, R., Zuther, E., Obel, N., Cacela, C., et al. (2007). Fructans from oat and rye: composition and effects on membrane stability during drying. Biochim. Biophys. Acta 1768, 1611-1619. doi: 10.1016/j.bbamem.2007.03.011

Hincha, D. K., Zuther, E., Hellwege, E. M., and Heyer, A. G. (2002). Specific effects of fructo- and gluco-oligosaccharides in the preservation of liposomes during drying. Glycobiology 12, 103-110. doi: 10.1093/glycob/12.2.103

Hincha, D. K., Zuther, E., and Heyer, A. G. (2003). The preservation of liposomes by raffinose family oligosaccharides during drying is mediated by effects on fusion and lipid phase transitions. Biochim. Biophys. Acta 1612, 172-177. doi: 10.1016/S0005-2736(03)00116-0

Hinrichs, W. L. J., Prinsen, M. G., and Frijlink, H. W. (2001). Inulin glasses for the stabilization of therapeutic proteins. Int. J. Pharmacol. 215, 163-174. doi: 10.1016/S0378-5173(00)00677-3

Hou, J., Huang, X., Sun, W., Du, C., Wang, C., Xie, Y., et al. (2018). Accumulation of water-soluble carbohydrates and gene expression in wheat stems correlates with drought resistance. J. Plant Physiol. 231, 182-191. doi: 10.1016/j.jplph.2018.09.017

Hsiao, T. C. (1973). Plant responses to water stress. Annu. Rev. Plant Physiol. 24, 519-570. doi: 10.1146/annurev.pp.24.060173.002511

Hummel, I., Pantin, F., Sulpice, R., Piques, M., Rolland, G., Dauzat, M., et al. (2010). Arabidopsis plants acclimate to water deficit at low cost through changes of carbon usage: an integrated perspective using growth, metabolite, enzyme, and gene expression analysis. Plant Physiol. 154, 357-372. doi: 10.1104/pp.110.157008

Hussain, S., Rao, M. J., Anjum, M. A., Zakir, S. E., Ali, M. A., Ahmad, N., et al. (2019). "Oxidative stress and antioxidant defense in plants under drought conditions," in Plant Abiotic Stress Tolerance, eds M. Hasanuzzaman, K. Hakeem, K. Nahar, and H. Alharby (Cham: Springer), 207-219. doi: 10.1007/978-3-030-06118-0_9

Iannucci, A., Pizzillo, M., Annicchiarico, G., Fragasso, M., and Fedele, V. (2016). Dynamics of accumulatio and partitioning of dry matter and fructooligosaccharides in plant fractions of forage cereals. Exp. Agric. 52, 188-202. doi: 10.1017/S0014479715000022

Incoll, L. D., Bonnett, G. D., and Gott, B. (1989). Fructans in the underground storage organs of some Australian plants used for food by aborigines. J. Plant Physiol. 134, 196-202. doi: 10.1016/S0176-1617(89)8 0055-0

IPCC (2019a). Global Warming of $1.5^{\circ}$ C. An International Panel on Climate Change Special Report on the Impacts of Global Warming of $1.5^{\circ} \mathrm{C}$ Above PreIndustrial Levels and Related Global Greenhouse Gas Emission Pathways, in the Context of Strengthening the Global Response to the Threat of Climate Change, Sustainable Development, and Efforts to Eradicate Poverty. Available online at: https://www.ipcc.ch/site/assets/uploads/sites/2/2019/06/SR15_Full_ Report_High_Res.pdf (accessed January 29, 2022).

IPCC (2019b). Climate Change and Land. An IPCC Special Report on Climate Change, Desertification, Land Degradation, Sustainable Land Management, Food Security, and Greenhouse Gas Fluxes in Terrestrial Ecosystems. Summary for Policymakers. Available online at: https://www.ipcc.ch/site/assets/uploads/ 2019/08/Edited-SPM_Approved_Microsite_FINAL.pdf (accessed September $14,2020)$.

Isah, T. (2019). Stress and defense responses in plant secondary metabolites production. Biol. Res. 52:39. doi: 10.1186/s40659-019-0246-3

Jahangir, M., Abdel-Farid, I. B., Kim, H. K., Cho, Y. H., and Verpoorte, R. (2009). Healthy and unhealthy plants: the effect of stress on the metabolism of Brassicaceae. Environ. Exp. Bot. 67, 23-33. doi: 10.1016/j.envexpbot.2009.06.007

Janku, M., Luhová, L., and Petrivalský, M. (2019). On the origin and fate of reactive oxygen species in plant cell compartments. Antioxidants 8:105. doi: 10.3390/antiox 8040105

Joaquim, E. O., Figueiredo-Ribeiro, R. C. L., Hayashi, A. H., and Carvalho, M. A. M. (2014). Inulin contents and tissue distribution in underground storage organs of Asteraceae species from the Brazilian rocky fields. Botany 92, 827-836. doi: 10.1139/cjb-2014-0087

Jones, M. M., and Turner, N. C. (1978). Osmotic adjustment in leaves of sorghum in response to water deficits. Plant Physiol. 61, 12-126. doi: 10.1104/pp.61.1.122

Kataoka, T., Watanabe-Takahashi, A., Hayashi, N., Ohnishi, M., Mimura, T., Buchner, P., et al. (2004). Vacuolar sulfate transporters are essential determinants controlling internal distribution of sulfate in Arabidopsis, Plant Cell 16, 2693-2704. $d$ doi: 10.1105/tpc.104.023960

Kaur, G., and Asthir, B. (2015). Proline: a key player in plant abiotic stress tolerance. Biol. Plant. 59, 609-619. doi: 10.1007/s10535-015-0549-3

Keunen, E., Peshev, D., Vangronsveld, J., Van Den Ende, W., and Cuypers, A. (2013). Plant sugars are crucial players in the oxidative challenge during abiotic stress: extending the traditional concept. Plant Cell Environ. 36, 1242-1255. doi: $10.1111 /$ pce. 12061

Khan, M. S., Ahmad, D., and Khan, M. A. (2015). Utilization of genes encoding osmoprotectants in transgenic plants for enhanced abiotic stress tolerance. Electron. J. Biotechnol. 18, 257-266. doi: 10.1016/j.ejbt.2015.04.002

Koch, G., Rolland, G., Dauzat, M., Bédiée, A., Baldazzi, V., Bertin, N., et al. (2019). Leaf production and expansion: a generalized response to drought stresses from cells to whole leaf biomass-a case study in the tomato compound leaf. Plants 8:409. doi: 10.3390/plants8100409

Krasensky, J., and Jonak, C. (2012). Drought, salt, and temperature stress-induced metabolic rearrangements and regulatory networks. J. Exp. Bot. 63, 1593-1608. doi: 10.1093/jxb/err460

Lawlor, D. W., and Cornic, G. (2002). Photosynthetic carbon assimilation and associated metabolism in relation to water deficits in higher plants. Plant Cell Environ. 25, 275-294. doi: 10.1046/j.0016-8025.2001.00814.x

Lawson, T., Oxborough, K., Morison, J. I. L., and Baker, N. R. (2003). The responses of guard and mesophyll cell photosynthesis to $\mathrm{CO}_{2}, \mathrm{O}_{2}$, light, and water stress in a range of species are similar. J. Exp. Bot. 254, 1743-1752. doi: $10.1093 /$ jxb/erg186

Le Roy, K., Lammens, W., Van Laere, A., and Van den Ende, W. (2008). Influencing the binding configuration of sucrose in the active sites of chicory fructan 1exohydrolase and sugar beet fructan 6-exohydrolase. New Phytol. 178, 572-580. doi: 10.1111/j.1469-8137.2008.02386.x

Li, J. Y., Li, C. Y., and Smith, S. M. (2017). Hormone Metabolism and Signaling in Plants. London: Academic Press, Elsevier.

Li, Y., Ye, W., Wang, M., and Yan, X. (2009). Climate change and drought: a risk assessment of crop-yield impacts. Climate Res. 39, 31-46. doi: 10.3354/cr00797

Li, Z., Shi, P., and Peng, Y. (2013). Improved drought tolerance through drought preconditioning associated with changes in antioxidant enzyme activities, gene expression and osmoregulatory solutes accumulation in white clover (Trifolium repens L.). Plant Omics 6, 481-489.

Liang, J., Zhang, J., and Wong, M. H. (1997). Can stomatal closure caused by xylem ABA explain the inhibition of leaf photosynthesis under soil drying? Photosynth. Res. 51, 149-159. doi: 10.1023/A:1005797410190

Lim, C. W., Baek, W., Jung, J., Kim, J. H., and Lee, S. C. (2015). Function of ABA in stomatal defense against biotic and drought stresses. Int. J. Mol. Sci. 16, 15251-15270. doi: 10.3390/ijms160715251

Livingston, D. P., and Henson, C. A. (1998). Apoplastic sugars, fructans, fructan exohydrolase, and invertase in winter oat: responses to second-phase cold hardening. Plant Physiol. 116, 403-408. doi: 10.1104/pp.116.1.403

Lončarić, A., Pichler, A., Rašić, N., Vukoja, I., Leventić, A., and Kopjar, M. (2018). Influence of phenol and sugar interactions on antioxidant activity of pomegranate juice. Acta Alim. 47, 203-209. doi: 10.1556/066.2018.47.2.9

López, M. G., Mancilla Margalli, N. A., and Mendoza Díaz, G. (2003). Molecular structures of fructans from Agave tequilana Weber var azul. J. Agric. Food Chem. 51, 7835-7840. doi: 10.1021/jf030383v

Luo, R., Song, X., Li, Z., Zhang, A., Yan, X., and Pang, Q. (2018). Effect of soil salinity on fructan content and polymerization degree in the sprouting tubers of Jerusalem artichoke (Helianthus tuberosus L.). Plant Physiol. Biochem. 125, 27-34. doi: 10.1016/j.plaphy.2018.01.025

Marschall, M. (2010). Photosynthetic responses, carbohydrate composition and invertase activity in fructan accumulating bryophytes (Porella platyphylla and Sphagnum flexuosum) under different environmental conditions (carbohydrate treatments, dark starvation, low temperature, desiccation). Acta Biol. Hung. 61(Supp.1), 120-129. doi: 10.1556/ABiol.61.2010.Suppl.12

Marschall, M., Proctor, M. C. F., and Smirnoff, N. (1998). carbohydrate composition and invertase activity of the leafy liverwort Porella platyphylla. New Phytol. 138, 343-353. doi: 10.1046/j.1469-8137.1998.00102.x

Martínez-Carraseo, R., Cervantes, E., Pérez, P., Morcuende, R., and Martín Del Molino, I. M. (1993). Effect of sink size on photosynthesis and carbohydrate content of leaves of three spring wheat varieties. Physiol. Plant. 89, 453-459. doi: 10.1111/j.1399-3054.1993.tb05198.x 
Meier, H., and Reid, J. S. (1982). "Reserve polysaccharides other than starch in higher plants," in Encyclopedia of Plant Physiology, eds F. A Loewus, and W. Tanner (Berlin: Springer Verlag), 418-471. doi: 10.1007/978-3-642-68275-9_11

Michiels, A., Van Laere, A., Van den Ende, W., and Tucker, M. (2004). Expression analysis of a chicory fructan 1-exohydrolase gene reveals complex regulation by cold. J. Exp. Bot. 55, 1325-1333. doi: 10.1093/jxb/erh153

Mittler, R. (2017). ROS are good. Trends Plant Sci. 22, 11-19. doi: 10.1016/j.tplants.2016.08.002

Mohammadi, F., Naghavi, M. R., Peighambari, S. A., Khosravi Dehaghi, N., Khaldari, I., Bravi, E., et al. (2021). Abscisic acid crosstalk with auxin and ethylene in biosynthesis and degradation of inulin-type fructans in chicory. Plant Biol. 23, 636-642. doi: 10.1111/plb.13252

Moller, I. M., Jensen, P. E., and Hansson, A. (2007). Oxidative modifications to cellular components in plants. Annu. Rev. Plant Biol. 58, 459-481. doi: 10.1146/annurev.arplant.58.032806.103946

Monti, A., Amaducci, M. T., Pritoni, G., and Venturi, G. (2005). Growth, fructan yield, and quality of chicory (Cichorium intybus L.) as related to photosynthetic capacity, harvest time, and water regime. J. Exp. Bot. 56, 1389-1395. doi: 10.1093/jxb/eri140

Morales, M., and Munné-Bosch, S. (2019). Malondialdehyde: facts and artifacts. Plant Physiol. 180, 1246-1250. doi: 10.1104/pp.19.00405

Morvan-Bertrand, A., Boucaud, J., Le Saos, J., and Prud'homme, M. P. (2001). Roles of the fructans from the leaf sheaths and from the elongating leaf bases in the regrowth following defoliation of Lolium perenne L. Planta 213, 109-120. doi: $10.1007 /$ s004250000478

Muller, B., Pantin, F., Génard, M., Turc, O., Freixes, S., Piques, M., et al. (2011). Water deficits uncouple growth from photosynthesis, increase $\mathrm{C}$ content, and modify the relationships between $\mathrm{C}$ and growth in sink organs. J. Exp. Bot. 62, 1715-1729. doi: 10.1093/jxb/erq438

Munns, R., and Sharp, R. E. (1993). Involvement of abscisic acid in controlling plant growth in soils of low water potential. Aust. J. Plant Physiol. 20, 425-437. doi: 10.1071/PP9930425

Nelissen, N., Sun, X. H., Rymen, B., Jikumaru, Y., Kojima, M., Takebayashi, Y., et al. (2018). The reduction in maize leaf growth under mild drought affects the transition between cell division and cell expansion and cannot be restored by elevated gibberellic acid levels. Plant Biotechnol. J. 16, 615-627. doi: 10.1111/pbi.12801

Nemati, F., Ghanati, F., Gavlighi, H. A., and Sharifi, M. (2018). Fructan dynamics and antioxidant capacity of 4-day-old seedlings of wheat (Triticum aestivum) cultivars during drought stress and recovery. Func. Plant Biol. 45, 1000-1008. doi: 10.1071/FP18008

Nishizawa, A., Yabuta, Y., and Shigeoka, S. (2008). Galactinol and raffinose constitute a novel function to protect plants from oxidative damage. Plant Physiol. 147, 1251-1263. doi: 10.1104/pp.108.122465

Noctor, G., and Foyer, C. H. (1998). Ascorbate and gluthatione: keeping active oxygen under control. Annu. Rev. Plant Physiol. Plant Mol. Biol. 49, 249-279. doi: 10.1146/annurev.arplant.49.1.249

Noctor, G., Mhamdi, A., and Foyer, C. H. (2014). The roles of reactive oxygen metabolism in drought: not so cut and dried. Plant Physiol. 164, 1636-1648. doi: 10.1104/pp.113.233478

Obata, T., and Fernie, A. R. (2012). The use of metabolomics to dissect plant responses to abiotic stresses. Cell. Mol. Life Sci. 69, 3225-3243. doi: 10.1007/s00018-012-1091-5

Ozturk, M., Unal, B. T., García-Caparrós, P., Khursheed, A., Gul, A., and Hasanuzzaman, M. (2021). Osmoregulation and its actions during the drought stress in plants. Physiol. Plant. 172, 1321-1335. doi: 10.1111/ppl.13297

Pasqualetti, V., Altomare, A., Guarino, M. P., Locato, V., Cocca, S., Cimini, S., et al. (2014). Antioxidant activity of inulin and its role in the prevention of human colonic muscle cell impairment induced by lipopolysaccharide mucosal exposure. PLoS ONE 9:e98031. doi: 10.1371/journal.pone.0 098031

Peshev, D., Vergauwen, R., Moglia, A., Hideg, E., and Van den Ende, W. (2013). Towards understanding vacuolar antioxidant mechanisms: a role for fructans? J. Exp. Bot. 64, 1025-1038. doi: 10.1093/jxb/ers377

Pilon-Smits, E. A. H., Ebskamp, M. J. M., Paul, M. J., Jeuken, M. J. W., Weisbeek, P. J., and Smeeken, S. C. M. (1995). Improved performance of transgenic fructanaccumulating tobacco under drought stress. Plant Physiol. 107, 125-130. doi: $10.1104 /$ pp.107.1.125
Pilon-Smits, E. H. A., Terry, N., Sears, T., and van Dun, K. (1999). Enhanced drought resistance in fructan-producing sugar beet. Plant Physiol. Biochem. 37, 313-317. doi: 10.1016/S0981-9428(99)80030-8

Pinhero, R. G., Rao, M. V., Palyath, G., Murr, D. P., and Fletcher, R. A. (1997). Changes in the activities of antioxidant enzymes and their relationship to genetic and paclobutrazol-induced chilling tolerance of maize seedlings. Plant Physiol. 114, 695-704. doi: 10.1104/pp.114.2.695

Pollock, C. J., and Cairns, A. J. (1991). Fructan metabolism in grasses and cereals. Annu. Rev. Plant. Physiol. Plant. Mol. Biol. 42, 77-101. doi: 10.1146/annurev.pp.42.060191.000453

Pollock, C. J., and Lloyd, E. J. (1994). The metabolism of fructans during seed development and germination in onion (Allium cepa L.). New Phytol. 128, 601-605. doi: 10.1111/j.1469-8137.1994.tb04023.x

Pontis, H. G., and Del Campillo, E. (1985). "Fructan," in Biochemistry of Storage Carbohydrates in Green Plants, eds P. M. Dey, and R. A. Dixon (London: Academic Press), 205-227.

Poschet, G., Hannich, B., Raab, S., Jungkunz, I., Klemens, P. A. W., Krueger, S., et al. (2011). A novel Arabidopsis vacuolar glucose exporter is involved in cellular sugar homeostasis and affects the composition of seed storage compounds. Plant Physiol. 157, 1664-1676. doi: 10.1104/pp.111.186825

Ramanjulu, S., and Bartels, D. (2002). Drought- and desiccation-induced modulation of gene expression in plants. Plant Cell Environ. 25, 141-151. doi: 10.1046/j.0016-8025.2001.00764.x

Ranwala, A. P., and Miller, W. B. (2008). Analysis of nonstructural carbohydrates in storage organs of 30 ornamental geophytes by high-performance anionexchange chromatography with pulsed amperometric detection. New Phytol. 180, 421-433. doi: 10.1111/j.1469-8137.2008.02585.x

Reddy, A. R., Chaitanya, K. V., and Vivekanandan, M. (2004). Drought-induced responses of photosynthesis and antioxidant metabolism in higher plants. $J$. Plant Physiol. 161, 1189-1202. doi: 10.1016/j.jplph.2004.01.013

Rolland, F., Baena-Gonzalez, E., and Sheen, J. (2006). Sugar sensing and signaling in plants: conserved and novel mechanisms. Annu. Rev. Plant Biol. 57, 675-709. doi: 10.1146/annurev.arplant.57.032905.105441

Rook, F., Gerrits, N., Kortstee, A., van Kampen, M., Borrias, M., Weisbeek, P., et al. (1998). Sucrose-specific signalling represses translation of the Arabidopsis ATB2 bZIP transcription factor gene. Plant J. 15, 253-263. doi: 10.1046/j.1365-313X.1998.00205.x

Rose, V. (1804). Neues allgemeines. J. Chem. 3, 217-219.

Scarpeci, T. E., and Valle, E. M. (2008). Rearrangement of carbon metabolism in Arabidopsis thaliana subjected to oxidative stress condition: an emergency survival strategy. Plant Growth Regul. 54, 133-142. doi: 10.1007/s10725-007-9236-5

Schneider, S., Hulpke, S., Schulz, A., Yaron, I., Holl, J. H., Imlau, A., et al. (2011). Vacuoles release sucrose via tonoplast-localised SUC4-type transporters. Plant Biol. 14, 325-336. doi: 10.1111/j.1438-8677.2011.00506.x

Schulz, A., Beyhl, B., Marten, I., Wormit, A., Neuhaus, E., Poschet, G., et al. (2011). Proton-driven sucrose symport and antiport are provided by the vacuolar transporters SUC4 and TMT1/2. Plant J. 68, 129-136. doi: 10.1111/j.1365-313X.2011.04672.x

Schuppler, U., He, P. H., John, P. C. L., and Munns, R. (1998). Effect of water stress on cell division and cell-division- cycle 2-like cell-cycle kinase activity //in wheat leaves. Plant Physiol. 117, 667-678. doi: 10.1104/pp.117.2.667

Seiler, C., Harshavardhan, V. T., Rajesh, K., Reddy, P. S., Strickert, M., Rolletschek, H., et al. (2011). ABA biosynthesis and degradation contributing to ABA homeostasis during barley seed development under control and terminal drought-stress conditions. J. Exp. Bot. 62, 2615-2632. doi: 10.1093/jxb/erq446

Seki, M., Umezawa, T., Urano, K., and Shinozaki, K. (2007). Regulatory metabolic networks in drought stress responses. Curr. Opin. Plant Biol. 10, 296-302. doi: 10.1016/j.pbi.2007.04.014

Serraj, R., and Sinclair, T. R. (2002). Osmolyte accumulation: can it really help increase crop yield under drought conditions? Plant Cell Environ. 25, 333-341. doi: 10.1046/j.1365-3040.2002.00754.x

Shang, Y., Dai, C., Lee, M. M., Kwak, J. M., and Nam, K. H. (2016). BRI1-associated receptor kinase 1 regulates guard cell $\mathrm{ABA}$ signaling mediated by open stomata 1 in Arabidopsis. Mol. Plant 9, 447-460. doi: 10.1016/j.molp.2015.12.014

Shanker, A. K., Maheswari, M., Yadav, S. K., Desai, S., Bhanu, D., Bajaj, N., et al. (2014). Drought stress responses in crops. Funct. Integr. Genomics 14, 11-22. doi: 10.1007/s10142-013-0356-x 
Shao, H. B., Chu, L. Y., Jaleel, C. A., Manivannan, P., Panneerselvam, R., and Shao, M. A. (2009). Understanding water deficit stress-induced changes in the basic metabolism of higher plants-biotechnologically and sustainably improving agriculture and the ecoenvironment in arid regions of the globe. Crit. Rev. Biotechnol. 29, 131-151. doi: 10.1080/07388550902869792

Shao, H. B., Chu, L. Y., Jaleel, C. A., and Zhao, C. X. (2008). Water-deficit stressInduced anatomical changes in higher plants. Crit. Rev. Biol. 331, 215-225. doi: 10.1016/j.crvi.2008.01.002

Sharma, K. K., and Lavanya, M. (2002). Recent developments in transgenics for abiotic stress in legumes of the semi-arid tropics. JIRCAS Working Rep. 23, 61-73. Available online at: http://oar.icrisat.org/id/eprint/3611 (accessed October 2, 2020)

Sharma, P., Jha, A. B., Dubey, R. S., and Pessarakli, M. (2012). Reactive oxygen species, oxidative damage, and antioxidative defense mechanism in plants under stressful conditions. J. Bot. 217037, 1-26. doi: 10.1155/2012/217037

Shinozaki, K., and Yamaguchi-Shinozaki, K. (2007). Gene networks involved in drought stress response and tolerance. J. Exp. Bot. 58, 221-227. doi: $10.1093 / \mathrm{jxb} / \mathrm{erl} 164$

Shiomi, N. (1989). Properties of fructosyl transferases involved in the synthesis of fructan in Liliaceous plants. J. Plant Physiol. 134, 151-155. doi: $10.1016 /$ S0176-1617(89)80048-3

Shiomi, N. (1993). Structure of fructopolysaccharide (asparagosin) from roots of asparagus (Asparagus officinalis L.). New Phytol. 123, 263-270. doi: 10.1111/j.1469-8137.1993.tb03734.x

Shiomi, N., and Benkeblia, N. (2005). The metabolism of the fructooligosaccharides in onion bulbs: a comprehensive review. J. Appl. Glycosci. 52, 121-127. doi: 10.5458/jag.52.121

Siddique, M. R. B., Hamid, H., and Islam, M. S. (2000). Drought stress effects on water relations of wheat. Biot. Bull. Acal. Sin. 41, 35-39.

Skirycz, A., and Inzé, D. (2010). More from less: plant growth under limited water. Curr. Opin. Biotechnol. 21, 197-203. doi: 10.1016/j.copbio.2010. 03.002

Spollen, W. S., and Nelson, C. J. (1994). Response of fructan to water deficit in growing leaves of tall fescue. Plant Physiol. 106, 329-336. doi: $10.1104 /$ pp.106.1.329

Stoyanova, S., Geuns, J., Hideg, E., and Van den Ende, W. (2011). The food additives inulin and stevioside counteract oxidative stress. Int. J. Food Sci. Nutr. 62, 207-214. doi: 10.3109/09637486.2010.5 23416

Suárez-González, E. M., López, M. G., Délano-Frier, J. P., and Gómez-Leyva, J. F. (2014). Expression of the 1-SST and 1-FFT genes and consequent fructan accumulation in Agave tequilana and A. inaequidens is differentially induced by diverse (a)biotic-stress related elicitors. J. Plant Physiol. 171, 359-372. doi: 10.1016/j.jplph.2013.08.002

Sun, X., Zong, Y., Yang, S., Wang, L., Gao, J., Wang, J., et al. (2020). A fructan: the fructan 1-fructosyl-transferase gene from Helianthus tuberosus increased the PEG-simulated drought stress tolerance of tobacco. Hereditas 157:14. doi: 10.1186/s41065-020-00131-3

Suzuki, T., Maeda, T., Grant, S., Grant, G., and Sporns, P. (2013). Confirmation of fructans biosynthesized in vitro from $\left[1-{ }^{13} \mathrm{C}\right]$ glucose in asparagus tissues using MALDI-TOF MS and ESI-MS. J. Plant Physiol. 170, 715-722. doi: 10.1016/j.jplph.2012.12.005

Tardieu, F., Reymond, M., Hamard, P., Granier, C., and Muller, B. (2000). Spatial distributions of expansion rate, cell division rate and cell size in maize leaves: a synthesis of the effects of soil water status, evaporative demand and temperature. J. Exp. Bot. 51, 1505-1514. doi: 10.1093/jexbot/51.350.1505

Taylor, I. B., Burbidage, A., and Thompson, A. J. (2000). Control of abscisic acid synthesis. J. Exp. Bot. 51, 1563-1574. doi: 10.1093/jexbot/51.350.1563

Thomas, H. (1990). Osmotic adjustment in Lolium perenne; its heritability and the nature of solute accumulation. Ann. Bot. 66, 521-530. doi: 10.1093/oxfordjournals.aob.a088061

Thomas, H., and James, A. R. (1999). Partitioning of sugars in Lolium perenne (perennial ryegrass) during drought and on rewatering. New Phytol. 142, 295-305. doi: 10.1046/j.1469-8137.1999.00388.x

Todaka, D., Zhao, Y., Yoshida, T., Yoshida, T., Kudo, M., Kidokoro, S., et al. (2017). Temporal and spatial changes in gene expression, metabolite accumulation and phytohormone content in rice seedlings grown under drought stress conditions. Plant J. 90, 61-78. doi: 10.1111/tpj.13468
Trethewey, J. A. K., and Rolston, M. P. (2009). Carbohydrate dynamics during reproductive growth and seed yield limits in perennial ryegrass. Field Crops Res. 112, 182-188. doi: 10.1016/j.fcr.2009.03.001

Trouverie, J., Thévenot, C., Rocher, J. P., Sotta, B., and Prioul, J. L. (2003). The role of abscisic acid in the response of a specific vacuolar invertase to water stress in the adult maize leaf. J. Exp. Bot. 54, 2177-2186. doi: 10.1093/jxb/erg234

Tuberosa, R., and Salvi, S. (2006). Genomics-based approaches to improve drought tolerance of crops. Trends Plant Sci. 11, 405-412. doi: 10.1016/j.tplants.2006.06.003

Uemura, M., and Steponkus, P. L. (2003). Modification of the intracellular sugar content alters the incidence of freeze-induced membrane lesions of protoplasts isolated from Arabidopsis thaliana leaves. Plant Cell Environ. 26, 1083-1096. doi: 10.1046/j.1365-3040.2003.01033.x

Ullah, N., Yüce Gökçe, N. M. O. Z., and Budak, H. (2017). Comparative metabolite profiling of drought stress in roots and leaves of seven Triticeae species. BMC Genom. 18:969. doi: 10.1186/s12864-017-4321-2

Urano, K., Maruyama, K., Ogata, Y., Morishita, Y., Takeda, M., Sakurai, N., et al. (2009). Characterization of the ABA-regulated global responses to dehydration in Arabidopsis by metabolomics. Plant J. 57, 1065-1078. doi: 10.1111/j.1365-313X.2008.03748.x

Valliyodan, B., and Nguyen, H. T. (2006). Understanding regulatory networks and engineering for enhanced drought tolerance in plants. Curr. Opin. Plant Biol. 9, 189-195. doi: 10.1016/j.pbi.2006.01.019

Valluru, R., and Van den Ende, W. (2008). Plant fructans in stress environments: emerging concepts and future prospects. J. Exp. Bot. 59, 2905-2916. doi: $10.1093 / \mathrm{jxb} / \mathrm{ern} 164$

Van den Ende, W. (2013). Multifunctional fructans and raffinose family oligosaccharides. Front. Plant Sci. 4:247. doi: 10.3389/fpls.2013.00247

Van den Ende, W., De Coninck, B., and Van Laere, A. (2004). Plant fructan exohydrolases: a role in signaling and defense? Trends Plant Sci. 9, 523-528. doi: 10.1016/j.tplants.2004.09.008

Van den Ende, W., and El-Esawe, S. K. (2013). Sucrose signaling pathways leading to fructan and anthocyanin accumulation: a dual function in abiotic and biotic stress responses? Environ. Exp. Bot. 108, 4-13. doi: 10.1016/j.envexpbot.2013.09.017

Van Den Ende, W., Michiels, A., De Roover, J., and Van Laere, A. (2002). Fructan biosynthetic and breakdown enzymes in dicots evolved from different invertases. Expression of fructan genes throughout chicory development. Sci. World J. 2, 1281-1295. doi: 10.1100/tsw.2002.288

Van den Ende, W., and Valluru, R. (2009). Sucrose, sucrosyl oligosaccharides, and oxidative stress: scavenging and salvaging? J. Exp. Bot. 60, 9-18. doi: 10.1093/jxb/ern297

van der Leij, M., Smith, S. J., and Miller, A. J. (1998). Remobilization of vacuolar stored nitrate in barley root cells. Planta 205, 64-72. doi: $10.1007 / \mathrm{s} 004250050297$

Van der Meer, I. M., Ebskamp, M. J. M., Visser, R. G. F., Weisbeek, P. J., and Smeekens, S. C. M. (1994). Fructan as a new carbohydrate sink in transgenic potato plants. Plant Cell 6, 561-570. doi: 10.2307/3869935

Vereyken, I. J., Chupin, V., Islamov, A., Kuklin, A., Hincha, D. K., and de Kruijff, B. (2003). The effect of fructan on the phospholipid organization in the dry state. Biophys. J. 85, 3058-3065. doi: 10.1016/S0006-3495(03)74724-9

Vergauwen, R., Van Laere, A., and Van den Ende, W. (2003). Properties of fructan:fructan 1-fructosyltransferases from chicory and globe thistle, two Asteracean plants storing greatly different types of inulin. Plant Physiol. 133, 391-401. doi: 10.1104/pp.103.026807

Vijn, I., and Smeekens, S. (1999). Fructan: more than a reserve carbohydrate. Plant Physiol. 120, 351-359. doi: 10.1104/pp.120.2.351

Virgona, J. M., and Barlow, E. W. R. (1991). Drought stress induces changes in the non-structural carbohydrate composition of wheat stems. Aust. J. Plant Physiol. 18, 239-247. doi: 10.1071/PP9910239

Wagner, W. A., and Wiemken, A. (1986). Properties and subcellular localization of fructan hydrolase in the leaves of barley (Hordeum vulgare L cv Gerbel). J. Plant Physiol. 123, 429-439. doi: 10.1016/S0176-1617(86)80227-9

Wei, H., Bausewein, A., Steininger, H., Su, T., Zhao, H., Harms, K., et al. (2016). Linking expression of fructan active enzymes, cell wall invertases and sucrose transporters with fructan profiles in growing taproot of chicory (Cichorium intybus): Impact of hormonal and environmental cues. Front. Plant Sci. 7:1806. doi: $10.3389 /$ fpls.2016.01806 
Xue, G., McIntyre, C. L., Glassop, D., and Shorter, R. (2008). Use of expression analysis to dissect alterations in carbohydrate metabolism in wheat leaves during drought stress. Plant Mol. Biol. 67, 197-214. doi: 10.1007/s11103-008-9311-y

Yancey, P. H. (1994). "Compatible and counteracting solutes," in Cellular and Molecular Physiology of Cell Volume Regulation," ed K. Strange (Boca Caron, FL: CRC Press), 81-109. doi: 10.1201/9780367812140-7

Yang, J., Zhang, J., Wang, Z., Zhu, Q., and Liu, L. (2004). Activities of fructan- and sucrose-metabolizing enzymes in wheat stems subjected to water stress during grain filling. Planta 220, 331-343. doi: 10.1007/s00425-004-1338-y

Yasin, H. J., and Bufler, G. (2007). Dormancy and sprouting in onion (Allium cepa L.) bulbs. I. Changes in carbohydrate metabolism. J. Hortic. Sci. Biotechnol. 82, 89-96. doi: 10.1080/14620316.2007.11512203

Yoshida, T., Mogami, J., and Yamaguchi-Shinozaki, K. (2014). ABA-dependent and ABA-independent signaling in response to osmotic stress in plants. Curr. Opin Plant Biol. 21, 133-139. doi: 10.1016/j.pbi.2014.07.009

Zhang, J., Chen, W., Dell, B., Vergauwen, R., Zhang, X., Mayer, J. E., et al. (2015). Wheat genotypic variation in dynamic fluxes of WSC components in different stem segments under drought during grain filling. Front. Plant Sci. 6:624. doi: 10.3389 /fpls.2015.00624

Zhu, J. K. (2002). Salt and drought stress signal transduction in plants. Annu. Rev. Plant Biol. 53, 247-273. doi: 10.1146/annurev.arplant.53.091401.143329
Zhu, X., Jing, Y., Chen, G., Wang, S. M., and Zhang, C. L. (2003). Solute levels and osmoregulatory enzyme activities in reed plants adapted to drought and saline habitats. Plant Growth Reg. 41, 165-172. doi: 10.1023/A:1027381 006811

Conflict of Interest: The author declares that the research was conducted in the absence of any commercial or financial relationships that could be construed as a potential conflict of interest.

Publisher's Note: All claims expressed in this article are solely those of the authors and do not necessarily represent those of their affiliated organizations, or those of the publisher, the editors and the reviewers. Any product that may be evaluated in this article, or claim that may be made by its manufacturer, is not guaranteed or endorsed by the publisher.

Copyright (c) 2022 Benkeblia. This is an open-access article distributed under the terms of the Creative Commons Attribution License (CC BY). The use, distribution or reproduction in other forums is permitted, provided the original author(s) and the copyright owner(s) are credited and that the original publication in this journal is cited, in accordance with accepted academic practice. No use, distribution or reproduction is permitted which does not comply with these terms. 